\title{
Who's Adopting the Smarter Lunchroom Approach? Individual Characteristics of Innovative Food Service Directors
}

\author{
Gnel Gabrielyan, $\mathrm{PhD}^{1}$, Drew S. Hanks, $\mathrm{PhD}^{1}$, Kathryn Hoy, MFN, RD, $\mathrm{CDN}^{1}$, David R. Just, $\mathrm{PhD}^{1}$, Brian \\ Wansink, $\mathrm{PhD}^{1}$ \\ ${ }^{1}$ Cornell University,475 Warren Hall, Ithaca, NY 14853 USA
}

Gnel Gabrielyan, PhD, is a Research Associate at the Charles H. Dyson School of Applied Economics and Management, Cornell University, 475 Warren Hall, Ithaca, NY 14853 USA

Drew S. Hanks, PhD -is currently an Assistant Professor, Ohio State University, Columbus, Ohio

Email: hanks.46@osu.edu

Kathryn Hoy, MFN, RD, CDN is the Manager of the B.E.N. Center, Cornell University, 475 Warren Hall, Ithaca, NY14853 USA Email: kih7@cornell.edu

David R. Just, PhD is a Professor at the Charles H. Dyson School of Applied Economics, Cornell University, 475 Warren Hall, Ithaca, NY 14853 USA Email:drj3@cornell.edu

Brian Wansink, PhD (Corresponding Author) Professor of Marketing, Cornell University 475 Warren Hall, Ithaca, NY 14853 USA t.607.255.2191 f. 607.255.9984 Email: fblsubmissions@cornell.edu

(C) 2016. This manuscript version is made available under the Elsevier user license http://www.elsevier.com/open-access/userlicense/1.0/ 


\title{
"Who's Adopting the Smarter Lunchroom Approach? \\ Individual Characteristics of Innovative Food Service Directors"
}

\begin{abstract}
School cafeterias and, subsequently, food service directors (FSDs) play a vital role in feeding children in the U.S. This study investigates which FSDs with different characteristics and organizational affiliations are most willing to embrace and implement new programs in their cafeterias.

In 2014 we surveyed a representative sample of 8143 school FSDs across the U.S. regarding their knowledge and use of innovative methods that encourage children to select healthy food options. Nearly all of the surveyed FSDs (93\%) are aware of behavioral strategies to promote healthier eating in school lunchrooms, and nearly $93 \%$ report having made at least one change in their lunchroom. Male FSDs are more likely to be aware of new programs, though they are less likely to adopt them relative to female FSDs. In addition, membership in a professional organization increases awareness as well as the number of changes made by 0.14 $(p<0.01)$. Finally, 22\% of all respondents say they know about the Smarter Lunchrooms approach, a set of research-based lunchroom behavioral strategies that positively influence children to select healthy foods.

The findings highlight the importance of participation in professional associations which provide career-building activities for school FSDs increasing awareness and adoption of innovative approaches to motivate children to eat the nutritious foods. Given these findings, there is reason for policy makers and school districts to consider allocating funds to encourage FSDs to engage more fully in professional association meetings and activities.
\end{abstract}

Key Words: choice behavior; food service directors; innovation; school nutrition 


\section{Who's Adopting the Smarter Lunchroom Approach?}

\section{Individual Characteristics of Innovative Food Service Directors}

Children are among the most important segments of the population to educate and encourage towards a healthier lifestyle. Eating behaviors developed at younger ages persist into adulthood (Birch, 1999; Westenhoefer, 2002), and childhood obesity strongly predicts adult obesity (Schaub \& Marian, 2011). Moreover, intake of nutritionally rich foods in children is important for physical development, academic achievement, and overall health (Guthrie \& Buzby, 2002). Much of the focus has been on encouraging children to eat more fruits and vegetables which can help maintain healthy weight (Rolls, Ello-Martin, \& Tohill, 2004). Given the large number of children eating a school lunch and the importance of developing proper eating habits at younger ages (Birch, 1999; Eliassen, 2011), school cafeterias are prime opportunity to encourage children to take and eat relatively nutritious foods, and, specifically, fruits and vegetables.

Approximately 31.7 million children participate in the National School Lunch Program (NSLP) (Fox \& Condon, 2012). Despite improved school lunch standards, children still do not eat anywhere near the recommended number of servings of fruits and vegetables (Kraak, Story, \& Swinburn, 2013; Briefel, Wilson, \& Gleason, 2009). While federal state and local policies regulate what foods can be offered, school food service directors (FSDs) manage the day-to-day operations in school cafeterias, and are primarily responsible for preparing menus, ordering, preparing, and distributing the foods (Osganian et al., 1996). FSDs have tremendous opportunity to influence the eating environment and the overall experience students have in the school lunchroom which for the most part fall outside of the school lunch regulations. 
While the USDA places some training requirements on FSDs, along with other school nutrition-related personnel (U.S. Department of Agriculture: Food and Nutrition Service, 2015), they typically have a significant amount of autonomy. FSDs usually report directly to school superintendents or act as assistant superintendents themselves (School Nutrition Association, 2015). A high percentage of FSDs participate in setting local school food policies (French, Story, Fulkerson, \& Gerlach, 2003). There is significant interest among FSDs, to participate in development of nutritional policies at the state or federal levels (McDonnell, Probart, Weirich, Hartman, \& Bailey-Davis, 2006; Roberts, Pobocik, Deek, Besgrove, \& Prostine, 2009) perhaps due to their significant practical experience that can come into conflict with the views of policymakers.

Unfortunately, FSDs with less experience are slow to adopt new techniques (Johnson \& Chambers, 2000) designed to encourage children to take and eat healthier meals. FSDs do respond to training and external suggestions in regards to their own beliefs and practices (Lytle et al., 2006). The purpose of this study is to identify the characteristics of FSDs who are early adopters of new and innovative methods designed to encourage healthy behaviors in school lunchrooms and how career building activities, such as professional training, affect this adoption.

Adoption of new technologies in food service can be costly and will often occur only when it becomes necessary for survival to meet regulatory demands (Oronsky \& Chathoth, 2007). Successful dining establishments are characterized by innovation (Jogaratnam, Tse, \& Olsen, 1999), and restrictive regulations can often interfere with innovation, leading to lower sales and sales growth (Jogaratnam, 2002). Like many other food service establishments, school cafeterias compete for customers (children can bring a lunch, or decide to eat after school) and face an environment with very tight budgets. Additionally, in order to receive subsidies for 
NSLP meals these FSDs are required to comply with strict regulations on the meals they offer while at the same time satisfy taste preference of children. This environment poses a challenge for FSDs to innovate or even consider adopting new methods that might increase student satisfaction or improve the healthfulness of the lunches.

While there has been a great deal of discussion regarding the most effective methods to address school nutrition (Clark, Goyder, Bissell, Blank, \& Peters, 2007; Schwartz, 2007), there is strong evidence indicating the power of the presentation and placement of food in encouraging more nutritious choices (Wansink, 2014). Such behavioral methods are often low cost both in terms of money and labor and can be easily adopted by FSDs to increase nutrient intake and satisfy their student clients (Hanks, Just, Smith, \& Wansink, 2012). Small changes that do not require substantial investment can change participants' consumption behavior (Just, 2009; Meyers \& Stunkard, 1980; Wansink, Just, Hanks, \& Smith, 2013) and increase the desirability of healthier foods (Volkow et al., 2002) often without altering the actual food choices available (Wansink 2004). The Smarter Lunchrooms (SL) approach is a set of research based environmental principles designed to be easily implemented in school cafeterias to encourage more nutritious choices among the children.

The SL approach uses behavioral economics, psychology, and food marketing to change food consumption habits with an emphasis on improving the diets and health of participants in the National School Lunch Program (Just, Mancino, \& Wansink, 2007). The general idea of the program is to make healthier options more convenient, visible and appealing than less healthy options, subsequently increasing the probability of choosing those healthier options. The effectiveness and persistence of different SL techniques have been analyzed in several studies. One study shows that a SL makeover including a combination of several environmental changes 
increased fruit and vegetable consumption by $18 \%$ and $25 \%$, respectively (Hanks, Just, \& Wansink, 2012). Others found that using attractive names for healthy food options in a cafeteria significantly increased the consumption of these food items by $16 \%$ with a long lasting effect (Wansink, Just, Payne, \& Klinger, 2012).

Sponsored by USDA and championed by the current administration, there has been some evidence of wide dissemination and adoption of SL. This may be in part due to the inclusion of SL in the Healthier US School Challenge (HUSSC) criteria, a program offering monetary rewards to schools that comply with certain health and nutrition standards. Many FSDs are primarily trained in management or nutrition and may find such behavioral approaches foreign. No prior research has been done to determine the factors that impact the adoption of the SL approach.

In this article, we use results from a nationally representative survey of FSDs to identify reasons why they implemented behavioral changes in their cafeterias. While prior research shows that SL techniques induce a significant increase in fruit, vegetable and white milk consumption and a decrease in high calorie product intake, this is of little consequence if schools in need of improvement are not willing to adopt the techniques (Hanks, Just, \& Wansink, 2012, 2013; Just \& Wansink, 2009).

\section{METHOD}

\section{Analysis Plan}

\section{$\underline{\text { Research questions }}$}

The survey for this study was designed to identify specific FSD characteristics that impact the adoption of new techniques to facilitate healthy food choice in school cafeterias. Data were obtained from a survey administered from March to May 2014 to a nationally representative 
sample of FSDs. The survey questions were further divided into three main groups: 1) FSD characteristics (gender, years of experience, FSDs' professional organizational affiliations, number of environmental/behavioral techniques used); 2) school characteristics (grade levels, number of students, percent of students qualifying for a free and reduced meals, urban index); and 3) SL engagement (awareness of SL approach, participation in SL training, used a SL proposed change).

The survey included questions asking FSDs to report lunchroom on whether some specific strategies were used, including: whether fresh fruit is available within 3 feet of the cash register, how the fresh fruit is displayed, whether attractive names were used to describe vegetables, whether white milk was easier to reach than other beverages, whether white milk comprised one-third of all beverages in the cafeteria's milk case, whether there was a grab-andgo reimbursable meal available, and whether the first entrée offered on the lunch line was the highlighted entrée of the day.

\section{$\underline{\text { Data Sources }}$}

This study was approved by the University Institutional Review Board. The relevance and clarity of the questions and overall effectiveness of the survey were pre-tested with FSDs local to the university sponsoring the study. Following this initial pre-testing, the national survey was administered using Research Now (Research Now Group, 2016) and Lucid (Lucid, 2016) online survey platforms. Invitations and instructions for accessing the online survey were all sent via mail.

In order to maximize the response rate to the finalized online survey three different types of external messaging on the mail envelopes were tested for effectiveness. An initial set of sixthousand letters were sent to a randomly selected sample of schools throughout the US. While all 
invitation letters contained the same information inside, three different types of envelopes were used. Two-thousand letters were stuffed inside envelopes with the FSDs mail address and no other logos. A second group of two-thousand invitations were enclosed in response requested envelope with the University and USDA logos on the front. The last group of letters were enclosed in envelopes which advertised that participants could be entered into a drawing for a $\$ 500$ VISA gift card.

After these six-thousand letters were mailed out and responses received $(\mathrm{N}=428)$, the envelopes with the USDA and University logos resulted in the greatest responses $(\mathrm{N}=167)$. Using this envelope, approximately 90,000 letters were sent to school FSDs (including schools in the initial six-thousand that did not respond). The list of schools surveyed is from the Common Core Data ${ }^{1}$ set (U.S. Department of Education, 2014), which includes all public schools within the US. Each respondent had a chance to be entered into a drawing for a gift card valued at $\$ 500$ that could be used in any store that accepts debit cards.

After all envelopes were mailed and responses received, a total of 8143 FSDs $(9.05 \%$ of total number of surveys mailed) completed the survey. Specifically, 6,509 FSDs (7.23\%) filled out the online questionnaire after receiving the initial letter-based request. Of the schools that did not respond, phone calls were made to $26,638(29.60 \%)$ randomly chosen schools and an additional 1,634 (1.82\%) observations were collected via phone interviews.

\section{Analysis Approaches}

Two regression models are used to analyze the impact of FSD-specific and schoolspecific characteristics on the probability of making a change and the total number of changes

\footnotetext{
${ }^{1}$ U.S. Department of Education's National Center for Education Statistics annually collects fiscal and nonfiscal data about all public schools, public school districts and state education agencies in the U.S. The data that includes information describing schools and school districts, descriptive information (demographics and fiscal data) about students and staff is provided by state education agency officials.
} 
made (Table 3). Stata 14 (StataCorp, 2015), was used for data analysis. The first regression analyzes the effect of the schools' location, school grade, percent of students receiving lunch, percent of students receiving a free or reduced lunch, whether or not the FSD has received any training, and the FSD's gender, years of experience, and affiliation with any professional organization on whether or not the FSD has implemented at least one SL technique in the lunchroom. Since the dependent variable is binary we use a generalized linear model with a logit link function to estimate the effects. In the second model an ordinary least squares model is used to test the impact that the same set of covariates has on the number of techniques used in the lunchroom. ANOVA is used to analyze the variance between different organizational affiliations and the probability of receiving training in SL.

\section{RESULTS}

\section{$\underline{\text { Data Analysis }}$}

Descriptive statistics resulting from the survey are provided in Table 1 . The vast majority of respondents are female (90.64\%). FSDs with 21 years of work experience or more comprise $25 \%$ of the respondents while on average, respondents report approximately 14.5 years of experience. Half of the FSDs (50.82\%) are members of their respective states' School Nutrition Association (SNA), with smaller percentages belonging to the National SNA (NSNA) (14.32\%), other professional associations (5.15\%), the Academy of Nutrition and Dietetics (AND) (1.65\%), and Society for Nutrition Education and Behavior (SNEB) (0.84\%). Many FSDs (8.25\%) have more than one organizational membership. Finally, 38\% of sampled FSDs are not a member of any professional organization. Those not affiliated with any professional organization might work in districts with limited funding for professional development. 
Over half of the respondents work in elementary schools (52.07\%), 27.52\% work in high schools, and $20.41 \%$ work in middle schools. This reflects the fact that relatively more elementary schools than secondary schools. Most of the lunchrooms served 100-500 students a day with $45-54 \%$ of students, on average, qualifying for free or reduced meals. Schools having more than $75 \%$ of students that qualify for free and reduced meals comprise $23.58 \%$ of total schools. Most of the schools (62.38\%) serve between 100 and 499 students daily in their cafeterias followed by schools that serve between 500 and 999 students (22.82\%).

Information about schools' geo-political locations and other school characteristics are also included in Common Core Data (U.S. Department of Education, 2014). This allows us to collect more detailed information about school socio-demographic descriptors. We create an urban index based on this data. Of those responding, $43.9 \%$ of schools are located in rural areas (census-defined rural territories that are more than 10 miles from an urban cluster) followed by $12.9 \%$ in suburban areas (territories outside a principal city with population of 250,000 or more, but inside urbanized areas), $18.6 \%$ are located in urban areas (territories inside the urbanized area and inside a principal city with populations of 250,000 or more), and lastly $15.6 \%$ are situated in towns (territories inside an urban cluster that can be more than 35 miles of an urbanized area).

Survey respondents indicate whether or not they are aware of and have adopted lunchroom strategies designed to encourage students to take and eat healthier meals. Nearly all of the FSDs (93\%) are at least aware of these strategies and the same number have actually adopted a strategy in their lunch room, though not necessarily following any specific program. In fact, 79.6\% FSDs report displaying fresh fruit close to cash register, 70.7\% report that white milk comprises at least one-third of all milk options, and $78.5 \%$ report that the first entrée on the line is the highlighted entrée of the day. On the other hand, only $27 \%$ of FSDs use attractive 
names to promote vegetables, $37.3 \%$ make grab-and-go reimbursable meals available, and 38.8\% display fresh fruit in a bowl or a basket instead of in metal pans or on trays. These latter strategies may have relatively lower adoption rates because they require additional materials and/or planning in order to carry them out.

Notably, these strategies - increasing attractiveness and availability of fruit, naming vegetables, and serving grab-and go meals - are key elements of the SL program. While 93\% of respondents report using some behavioral strategy, only $22 \%$ acknowledge previous exposure to the program. Of these SL aware respondents, $60 \%$ of respondents have received at least some type of training, with seminars being the most popular (21.3\% of those who had heard of SL). Furthermore, $43 \%$ of these SL aware respondents report having made a change based on SL training.

Regression results are reported in Tables 2-4. In Table 2 we report the impact of FSD and school characteristics on the probability of SL approach awareness (column 1 - a logit model), the probability of making at least one SL proposed change (column2 - a logit model), and the total number of techniques used (column 3 - an OLS model). The results show that female FSDs are less likely to be aware of the SL approach $(\mathrm{p}<0.01)$. At the same time, while male FSDs are more aware of SL approach, female FSDs are more likely to make at least one SL proposed change $(\mathrm{p}<0.05)$ and an additional one out of 10 female FSDs makes at least one change $(p<0.10)$ relative to their male counterparts. Work experience dummy variables show that FSDs with 6-10 years, $11-15$ years and 16-20 years of experience are respectively $26 \%, 23 \%$, and $35 \%$ less likely to be aware of SL approach ( $\mathrm{p}<0.01, \mathrm{p}<0.05$, and $\mathrm{p}<0.01$, respectively) compared to those with less than 5 years of experience. 
Schools' urbanization $(\mathrm{p}<0.05)$ and type of school (middle $-\mathrm{p}<0.05$, high $-\mathrm{p}<0.05$ ) have a positive and statistically significant impact on the probability that an FSD will incorporate at least one SL proposed change in the lunchroom (Table 3). In addition, FSDs in schools that are in urbanized areas are more likely to use at least one SL technique $(\mathrm{p}<0.05)$ and, on average, make 0.04 more changes per each level of urban index $(\mathrm{p}<0.01)$.

As the number of students taking a qualifying NSLP meal increases (100 to 499, 500 to 999, and more than 1000), more changes are made with the respective effects of $0.25,0.35$ and $0.51(\mathrm{p}<0.01)$ (Table 3). However, the number of techniques used declines as the percentage of free and reduced lunches taken increases. Schools that have 35-44\% $(\mathrm{p}<0.01), 45-54 \%(\mathrm{p}<0.05)$, $55-64 \%(p<0.01)$, and 65-74\% $(p<0.05)$ of their students qualify for the free or reduced price meals used a significantly lower number of techniques in their cafeterias compared to schools where less than $25 \%$ of students qualify for free and reduced price meals.

As expected, there is a positive and significant relationship between FSDs' professional affiliations and both hearing about and receiving training in the SL program $(\mathrm{p}<0.01)$. ANOVA results in Table 4 further show the impact of nutritional organizations affiliation on probabilities of receiving SL training. There is a significant relationship between the types of training received and being a member of state's SNA $\left(\mathrm{F}_{(4,6501)}=5.15, \mathrm{p}<0.01\right)$. Webinars as a type of SL training have the highest rate of participation among FSDs who are a member of state's SNA (76.2\%) followed by seminars $(75.4 \%)$, lectures $(67.3 \%)$, online training $(59.3 \%)$, and other $(56.8 \%)$. FSDs that report being members of SNEB did not report any type of training. Only 68 FSDs were SNEB members out of 8,143 participants. Whether the FSDs make any change as a result of training also significantly varies across the type of training received $\left(\mathrm{F}_{(5,1396)}=148.79\right.$, $\mathrm{p}<0.01$ ). In this case seminar training encourages $69.7 \%$ of FSDs to make at least one change in 
their lunchroom compared to $66.8 \%$ resulting from lectures. Online trainings, webinars, and other training programs are relatively less successful in leading FSDs to make a change $(61.5 \%$, $55.4 \%$, and $56.8 \%$, respectively).

Furthermore, FSDs who have attended an SL training, regardless of the type of training, were more likely to have employed at least one SL strategy and, on average, employ 0.33 $(\mathrm{p}<0.01)$ more strategies in their cafeterias. Membership in a professional organization increases the number of changes made by $0.14(\mathrm{p}<0.01)$ but had a negligible impact on the overall probability that any change would be made.

The differences in SL awareness, training, and changes made based on the type of organization with which an FSD is affiliated are reported in Table 4. Since some FSDs are members of more than one organization there is overlap in the percentages. Notably, one-third of the FSDs enrolled in AND are aware of SL though only $7.5 \%$ are trained in the methods. Moreover, more than one out of every four FSDs declaring membership in their state's SNA are aware of SL and report the highest percentage (14.1) of SL trainees, though the next to lowest number of total changes made (3.6). Interestingly, one-fifth of the SNEB members in the sample are aware of SL and while none of them reported attending any training, these FSDs reported the largest number of changes made to their school lunchrooms (4.6). While the percentage declaring membership in the SNEB is small, these FSDs do appear motivated to make changes. Lastly, FSDs that are not members of any organization are least aware of SL and report implementing the fewest changes in their lunchrooms.

\section{DISCUSSION}


Even though male FSDs are more likely to be aware of SL approach, the results show that female FSDs are more active and they are more likely to have participated in a SL training session. Female FSDs are also more likely to employ at least one SL technique and make more behavioral changes to their cafeterias to facilitate healthy food consumption. These results run counter to the findings in literature which show that men are more willing to adopt new technologies in the workplace compared to their female counterparts (M. G. Morris, Venkatesh, \& Ackerman, 2005; Venkatesh \& Morris, 2000; Venkatesh, Morris, \& Ackerman, 2000). These authors, however, also find that while men make adoption decisions based on their perception of usefulness, women are more influenced by subjective norms, behavioral control and ease of use, which may explain our result. FSDs that have more than 5 years of experience are less inclined to make changes to their lunchrooms compared to FSDs that are new in the profession, though these results were not statistically significant in the second model. Similar findings are reported by Morris and Venkatesh (2000) who conclude that younger workers are more willing to adopt new technologies.

Interestingly, while the percentage of students taking an NSLP qualifying meal and the percentage receiving a free or reduced price lunch had no impact on the likelihood that the FSD any SL strategy, these factors do have a significant impact on the number of changes made. The urban index has a negative impact on the chance of SL awareness, but a positive impact on the chance that an FSD received an SL training, given awareness of the program. Poverty, race, food environments, and population density are hypothesized to impact the distribution of resources between different geopolitical regions (Richardson, Boone-Heinonen, Popkin, \& Gordon-Larsen, 2012). In addition, existing research shows that expected incomes of students from rural areas is lower compared to students from other regions (McCracken \& Barcinas, 1991) leading to 
regional income inequality. It is possible that schools that are in rural areas lack the financial resources to support professional development for FSDs but those FSDs who learn about new and innovative methods recognize their value and seek for more training. Consequently, FSDs operating in schools located in wealthier areas have a greater incentive to compete with outside food options since parents have greater amounts of disposable income.

To formally test the impact that professional membership has on the probability of SL adoption we use generalized linear models with a logit link function. Table 4 reports results from two regressions where we identify FSD specific characteristics that affect the probability of adopting the SL approach. In particular, the independent variables included in the regressions are urban index, gender of the FSD, years of experience (as dummy variables) and whether the FSD is a member of any organization. And the dependent variables are whether the FSD has heard of the SL approach, or given that the FSD has heard of SL, whether or not s/he has been trained in the methods.

One of the major and important findings is that FSDs' professional affiliation with any nutritional organization such as the state's SNA, the NSNA, or the AND significantly increases the awareness of a new program such as the SL program and the probability of having a SL training. Membership in these associations expose individuals to a variety of methods and opportunities and can greatly enhance the chance for success. National, state, and local organizations act as a platform where information dissemination happens in both directions; from organization to its members or between members themselves. E.g. organizational memberships increase the likelihood of adoption of new technologies or techniques (Abebaw \& Haile, 2013; Damanpour, 1987). Our results indicate that career building activities, such as trainings (seminars, webinars, online training, lecture/talk, or other) and participation in professional 
organizations, generally promote and actuate positive changes in school lunchrooms. Whereas, the number of years in the profession reduces total number of changes made.

These findings show that FSDs' individual characteristics play a vital role in their awareness and willingness to adopt novel approaches to encourage healthier food options at schools. And, as a result, FDSs' professional membership in nutritional organizations at the state and national level increases the probability of adoption of new approaches designed to improve students' consumption behavior in school cafeterias.

\section{CONCLUSIONS AND IMPLICATIONS FOR SCHOOL HEALTH}

Results from this study highlight the characteristics that differentiate "movers" and "shakers" in school food service from those who might either resist change or lack the financial resources and support to obtain the training and knowledge necessary to adopt new methods. Consistent with the literature, we find FSDs in school lunchrooms are more likely to innovate and adopt changes when they have career building opportunities (such as trainings provided through professional organizations) and work in areas in which the residents have more disposable cash. This presents a particularly important challenge in motivating change in school cafeterias with severely limited financial reserves and those which serve more households that qualify for free or reduced price meals. Since food insecurity, poor diets, and childhood obesity are most prevalent in these lower income neighborhoods, there is a great opportunity for policy makers to provide financial resources to FSDs to develop their set of skills that can have a measureable impact on foods children take and eat.

We find that the more seasoned FSDs are less likely to make changes in their cafeterias. Interestingly, however, the effect of the years of experience is small, suggesting that this factor 
carries minimal economic significance except for those at the end of their careers. Those with $20+$ years of experience make 0.6 or fewer changes, though they are not less likely to implement anything at all. These veteran school cafeteria managers seem to still be willing to adapt to the changing environments and learn new methods.

Most importantly, findings from this research help strengthen the efforts to improve the nutrition and health of students. Because FSDs' career development plays a vital role in awareness and adoption of new techniques promoting healthier food options, there is reason for school cafeterias and policy makers to consider dedicating more resources towards FSD training and membership in professional organizations, especially in districts that serve lower income children. In order to improve adoption rates of new programs, there is reason to reach out to the appropriate professional organizations at state and national levels and develop trainings and informational sessions designed to spread awareness and teach FSDs about new methods. These efforts can be explicitly tailored to engage school FSDs to make the adoption process more efficient.

Limitations -While these results provide original insights into the characteristics of FSDs willingness to adopt new programs, there are plenty of opportunities to expand the research. First, our study relies on cross-sectional data to analyze the impacts of FSD and school related characteristics on the adoption of new programs. Longitudinal data (repeated responses from each FSD overtime) would provide greater detail to better gauge the impact of trainings and other characteristics on program adoption. One of the benefits of panel data is that it would allow us to capture the impact of changes in FSD's professional affiliation and SL training on the adoption of the various changes in cafeteria proposed by SL program to promote healthier consumption. 
In addition, our survey gathered limited data on the personal characteristics of FSDs and did not ask for education, income, race, and other demographic characteristics that could result in differences in outcomes. Furthermore, we are unable to identify whether adoption of SL techniques was a function of underlying characteristics of the FSD or a result of training. Additional survey questions can help address these limitations.

Lessons Learned: As is the case with many large-scale surveys, survey development and review is crucial to the type and quality of data received. The survey instrument used in this study omitted several questions for the sake of brevity to lessen burden on respondents. To build upon this body of work, surveys defining social networks and individual characteristics of various level school lunch innovators would be merited. School context and detailed demographic profiles of survey participants could provide insights into the diffusion of innovation in this population.

Additionally, network models could be employed to better understand how and why some social networks (urban school districts) had higher rates of school lunchroom innovation adoption. Methodologically, the data set would be improved with repeated measures and possible qualitative inquiry regarding the appropriateness of the survey questions and social network definition.

Acknowledgements: This study was supported by the BEN Center, which receives funding from the Federal Government through USDA ERS grant number 59-5000-0-0090 


\section{REFERENCES}

Abebaw, D., \& Haile, M. G. (2013). The impact of cooperatives on agricultural technology adoption: Empirical evidence from Ethiopia. Food Policy, 38, 82-91. doi:http://dx.doi.org/10.1016/j.foodpol.2012.10.003

Birch, L. L. (1999). Development of food preferences. Annual review of nutrition, 19(1), 41-62.

Briefel, R. R., Wilson, A., \& Gleason, P. M. (2009). Consumption of Low-Nutrient, EnergyDense Foods and Beverages at School, Home, and Other Locations among School Lunch Participants and Nonparticipants. Journal of the American Dietetic Association, 109(2, Supplement), S79-S90. doi:http://dx.doi.org/10.1016/j.jada.2008.10.064

Clark, H., Goyder, E., Bissell, P., Blank, L., \& Peters, J. (2007). How do parents' child-feeding behaviours influence child weight? Implications for childhood obesity policy. Journal of Public Health, 29(2), 132-141.

Damanpour, F. (1987). The Adoption of Technological, Administrative, and Ancillary Innovations: Impact of Organizational Factors. Journal of Management, 13(4), 675-688. doi:10.1177/014920638701300408

Eliassen, E. K. (2011). The Impact of Teachers and Families on Young Children's Eating Behaviors. Young Children, 2, 66-84.

Fox, M. K., \& Condon, E. (2012). School Nutrition Dietary Assessment Study-IV: Summary of Findings. Retrieved from

French, S. A., Story, M., Fulkerson, J. A., \& Gerlach, A. F. (2003). Food environment in secondary schools: a la carte, vending machines, and food policies and practices. American journal of public health, 93(7), 1161-1168. 
Guthrie, J. F., \& Buzby, J. C. (2002). Several strategies may lower plate waste in school feeding programs. FOOD REVIEW-WASHINGTON DC-, 25(2), 36-42.

Hanks, A. S., Just, D. R., Smith, L. E., \& Wansink, B. (2012). Healthy convenience: nudging students toward healthier choices in the lunchroom. Journal of Public Health. doi:10.1093/pubmed/fds003

Hanks, A. S., Just, D. R., \& Wansink, B. (2012). Smarter Lunchrooms: Libertarian Paternalism Can Address New School Lunchroom Guidelines and Childhood Obesity. Available at SSRN 2079843.

Hanks, A. S., Just, D. R., \& Wansink, B. (2013). Smarter lunchrooms can address new school lunchroom guidelines and childhood obesity. The Journal of pediatrics, 162(4), 867-869.

Jogaratnam, G. (2002). Entrepreneurial Orientation and Environmental Hostility: An Assessment of Small, Independent Restaurant Businesses. Journal of Hospitality \& Tourism Research, 26(3), 258-277. doi:10.1177/1096348002026003004

Jogaratnam, G., Tse, E. C., \& Olsen, M. D. (1999). An Empirical Analysis of Entrepreneurship and Performance in the Restaurant Industry. Journal of Hospitality \& Tourism Research, 23(4), 339-353. doi:10.1177/109634809902300401

Johnson, B. C., \& Chambers, M. J. (2000). Foodservice Benchmarking: Practices, Attitudes, and Beliefs of Foodservice Directors. Journal of the American Dietetic Association, 100(2), 175-180. doi:http://dx.doi.org/10.1016/S0002-8223(00)00056-0

Just, D. R. (2009). Could behavioral economics help improve diet quality for nutrition assistance program participants? : DIANE Publishing. 
Just, D. R., Mancino, L., \& Wansink, B. (2007). Could Behavioral Economics Help Improve Diet Quality for Nutrition Assistance Program Participants? USDA-ERS Economic Research Report(43).

Just, D. R., \& Wansink, B. (2009). Smarter lunchrooms: Using behavioral economics to improve meal selection. Choices, 24(3), 1-7.

Kraak, V. I., Story, M., \& Swinburn, B. A. (2013). Addressing barriers to improve children's fruit and vegetable intake. The American journal of clinical nutrition, 97(3), 653-655. doi:10.3945/ajen.112.052605

Lucid. (2016). lucid. Retrieved from https://lucidconnects.com/company/about-lucid

Lytle, L. A., Kubik, M. Y., Perry, C., Story, M., Birnbaum, A. S., \& Murray, D. M. (2006). Influencing healthful food choices in school and home environments: Results from the TEENS study. Preventive medicine, 4-13. doi:http://dx.doi.org/10.1016/j.ypmed.2006.03.020

McCracken, J. D., \& Barcinas, J. D. T. (1991). High School and Student Characteristics in Rural and Urban Areas of Ohio.

McDonnell, E., Probart, C., Weirich, J. E., Hartman, T., \& Bailey-Davis, L. (2006). School Competitive Food Policies: Perceptions of Pennsylvania Public High School Foodservice Directors and Principals. Journal of the American Dietetic Association, 106(2), 271-276. doi:http://dx.doi.org/10.1016/j.jada.2005.10.034

Meyers, A. W., \& Stunkard, A. J. (1980). Food accessibility and food choice: A test of schachter's externality hypothesis. Archives of General Psychiatry, 37(10), 1133-1135. doi:10.1001/archpsyc.1980.01780230051007 
Morris, M. G., \& Venkatesh, V. (2000). AGE DIFFERENCES IN TECHNOLOGY ADOPTION DECISIONS: IMPLICATIONS FOR A CHANGING WORK FORCE. Personnel Psychology, 53(2), 375-403. doi:10.1111/j.1744-6570.2000.tb00206.x

Morris, M. G., Venkatesh, V., \& Ackerman, P. L. (2005). Gender and age differences in employee decisions about new technology: an extension to the theory of planned behavior. IEEE Transactions on Engineering Management, 52(1), 69-84. doi:10.1109/TEM.2004.839967

Oronsky, C. R., \& Chathoth, P. K. (2007). An exploratory study examining information technology adoption and implementation in full-service restaurant firms. International Journal of Hospitality Management, $\quad$ 26(4), $\quad$ 941-956. doi:http://dx.doi.org/10.1016/j.ijhm.2006.04.001

Osganian, S. K., Ebzery, M. K., Montgomery, D. H., Nicklas, T. A., Evans, M. A., Mitchell, P. D., . . Parcel, G. S. (1996). Changes in the Nutrient Content of School Lunches: Results from the CATCH Eat Smart Food Service Intervention. Preventive medicine, 25(4), 400412. doi:http://dx.doi.org/10.1006/pmed.1996.0072

Research Now Group, Inc. (2016). Research Now®. Retrieved from https://www.researchnow.com/about-us/

Richardson, A. S., Boone-Heinonen, J., Popkin, B. M., \& Gordon-Larsen, P. (2012). Are neighbourhood food resources distributed inequitably by income and race in the USA? Epidemiological findings across the urban spectrum. BMJ Open, 2(2). doi:10.1136/bmjopen-2011-000698

Roberts, S. M., Pobocik, R. S., Deek, R., Besgrove, A., \& Prostine, B. A. (2009). A qualitative study of junior high school principals' and school food service directors' experiences with 
the Texas school nutrition policy. Journal of nutrition education and behavior, 41(4), 293-299.

Rolls, B. J., Ello-Martin, J. A., \& Tohill, B. C. (2004). What Can Intervention Studies Tell Us about the Relationship between Fruit and Vegetable Consumption and Weight Management? (Vol. 62).

Schaub, J., \& Marian, M. (2011). Reading, Writing, and Obesity: America's Failing Grade in School Nutrition and Physical Education. Nutrition in Clinical Practice, 26(5), 553-564. doi:10.1177/0884533611416820

School Nutrition Association. (2015). School Nutrition Professionals: Roles \& Responsibilities,. Retrieved from https://schoolnutrition.org/AboutSchoolMeals/SNPRolesResponsibilities/

Schwartz, M. B. (2007). The influence of a verbal prompt on school lunch fruit consumption: a pilot study. International Journal of Behavioral Nutrition and Physical Activity, 4(6), 5868-5864.

StataCorp. (2015). Stata Statistical Software: Release 14. College Station, TX: StataCorp LP.

U.S. Department of Agriculture: Food and Nutrition Service. (2015). School Meals: Professional Standards. Retrieved from http://www.fns.usda.gov/school-meals/professional-standards

U.S. Department of Education. (2014). Common Core of Data: Public Elementary/Secondary School Universe Survey Data. from Institute of Education Sciences, National Center for Education Statistics http://nces.ed.gov/ccd/pubschuniv.asp

Venkatesh, V., \& Morris, M. G. (2000). Why Don't Men Ever Stop to Ask for Directions? Gender, Social Influence, and Their Role in Technology Acceptance and Usage Behavior. MIS Quarterly, 24(1), 115-139. doi:10.2307/3250981 
Venkatesh, V., Morris, M. G., \& Ackerman, P. L. (2000). A Longitudinal Field Investigation of Gender Differences in Individual Technology Adoption Decision-Making Processes. Organizational Behavior and Human Decision Processes, 83(1), 33-60. doi:http://dx.doi.org/10.1006/obhd.2000.2896

Volkow, N. D., Wang, G.-J., Fowler, J. S., Logan, J., Jayne, M., Franceschi, D., . . Pappas, N. (2002). "Nonhedonic" food motivation in humans involves dopamine in the dorsal striatum and methylphenidate amplifies this effect. Synapse, 44(3), 175-180. doi:10.1002/syn.10075

Wansink, B. (2004). Environmental Factors That Increase the Food Intake and Consumption Volume of Unknowing Consumers. Annual review of nutrition, 24, 455-479.

Wansink, B. (2014). Slim by Design: HarperCollins.

Wansink, B., Just, D. R., Hanks, A. S., \& Smith, L. E. (2013). Pre-Sliced Fruit in School Cafeterias: Children's Selection and Intake. American journal of preventive medicine, 44(5), 477-480. doi:http://dx.doi.org/10.1016/j.amepre.2013.02.003

Wansink, B., Just, D. R., Payne, C. R., \& Klinger, M. Z. (2012). Attractive names sustain increased vegetable intake in schools. Preventive medicine, 55(4), 330-332.

Westenhoefer, J. (2002). Establishing dietary habits during childhood for long-term weight control. Annals of nutrition \& metabolism, 46, 18-23. 
Table 1. Definitions and Summary Statistics of the Food Service Director (FSD) Related Variables $(\mathrm{n}=\mathbf{8 , 1 4 3 )}$

\begin{tabular}{|c|c|c|c|}
\hline Variable name & Definition & Description & $\begin{array}{l}\text { Freq. } \\
(\%)\end{array}$ \\
\hline \multicolumn{4}{|c|}{ FSD specific characteristics } \\
\hline Gender & A dummy variable that identifies FSDs' gender & $\begin{array}{l}0 \text { if male } \\
1 \text { if female }\end{array}$ & $\begin{array}{r}9.36 \\
90.64\end{array}$ \\
\hline Years of Experience & $\begin{array}{l}\text { A categorical variable that identifies the number of } \\
\text { years FSDs worked in school-based food service }\end{array}$ & $\begin{array}{l}1 \text { if } 1-5 \text { years } \\
2 \text { if } 6-10 \text { years } \\
3 \text { if } 11-15 \text { years } \\
4 \text { if } 16-20 \text { years } \\
5 \text { if } 21 \text { years or more }\end{array}$ & $\begin{array}{l}17.49 \\
19.34 \\
19.62 \\
18.38 \\
25.16\end{array}$ \\
\hline $\begin{array}{l}\text { Organizational } \\
\text { Affiliation }-1 *\end{array}$ & $\begin{array}{l}\text { A variable that identifies if FSDs belong to any of } \\
\text { the following professional organizations }\end{array}$ & $\begin{array}{l}\text { State's School Nutrition Association } \\
\text { The National School Nutrition } \\
\text { Association } \\
\text { Academy of Nutrition and Dietetics } \\
\text { Society for Nutrition Education and } \\
\text { Behavior } \\
\text { Other } \\
\text { None } \\
\text { Member to more than one } \\
\text { organization }\end{array}$ & $\begin{array}{r}50.82 \\
14.32 \\
1.65 \\
0.84 \\
5.15 \\
38.00 \\
8.25\end{array}$ \\
\hline $\begin{array}{l}\text { Organizational } \\
\text { Affiliation }-2\end{array}$ & $\begin{array}{l}\text { A dummy variable that identifies if FSDs belong to } \\
\text { any professional organization or not }\end{array}$ & 1 if member to any organization & 62.00 \\
\hline Changes made & $\begin{array}{l}\text { A continuous variable that shows the total number of } \\
\text { environmental (behavioral) changes FSDs made to } \\
\text { encourage children to select healthier food items in } \\
\text { school cafeterias }\end{array}$ & $\begin{array}{l}0 \text { changes made } \\
1 \text { change made } \\
2 \text { changes made } \\
3 \text { changes made }\end{array}$ & $\begin{array}{r}0.77 \\
5.44 \\
15.80 \\
27.23\end{array}$ \\
\hline
\end{tabular}


4 changes made

5 changes made

6 changes made

0 otherwise

38.00

\section{School specific characteristics}

\begin{tabular}{|c|c|c|c|}
\hline Grade & $\begin{array}{l}\text { A categorical variable that identifies the grade level } \\
\text { that FSDs' lunchroom serves }\end{array}$ & $\begin{array}{l}1 \text { if elementary } \\
2 \text { if middle } \\
3 \text { if high }\end{array}$ & $\begin{array}{l}52.07 \\
20.41 \\
27.52\end{array}$ \\
\hline Number of Students & $\begin{array}{l}\text { A categorical variable that identifies the average } \\
\text { number of students that FSDs' lunchroom feeds } \\
\text { every day }\end{array}$ & $\begin{array}{l}1 \text { if less than } 100 \\
2 \text { if } 100-499 \\
3 \text { if } 500-999 \\
4 \text { if } 1,000-1,999 \\
5 \text { if } 2,000-2,999 \\
6 \text { if } 3,000-3,999 \\
7 \text { if } 4,000 \text { and more }\end{array}$ & $\begin{array}{r}9.60 \\
62.38 \\
22.82 \\
4.45 \\
0.45 \\
0.11 \\
0.18\end{array}$ \\
\hline Percent of Students & $\begin{array}{l}\text { A categorical variable that shows what percentage of } \\
\text { FSDs' student population qualifies for a free and } \\
\text { reduced meals }\end{array}$ & $\begin{array}{l}1 \text { if less than } 25 \% \\
2 \text { if } 25-34 \% \\
3 \text { if } 35-44 \% \\
4 \text { if } 45-54 \% \\
5 \text { if } 55-64 \% \\
6 \text { if } 65-74 \% \\
7 \text { if } 75 \% \text { or more }\end{array}$ & $\begin{array}{l}15.39 \\
12.22 \\
12.88 \\
14.25 \\
11.42 \\
10.27 \\
23.58\end{array}$ \\
\hline Urban Index & $\begin{array}{l}\text { An index about the urban and rural classifications of } \\
\text { locales that the schools are in - by Common Core of } \\
\text { Data }\end{array}$ & $\begin{array}{l}1 \text { if in remote rural area } \\
2 \text { if in distant rural area } \\
3 \text { if in fringe rural area } \\
4 \text { if in remote town }\end{array}$ & $\begin{array}{r}11.03 \\
16.51 \\
16.39 \\
5.85\end{array}$ \\
\hline
\end{tabular}


5 if in distant town

6 if in fringe town

7 if in small suburb

8 if in midsize suburb

9 if in large suburb

10 if in small city

11 if in midsize city

12 if in large city

Missing data

\section{Smarter Lunchrooms specific characteristics}

\begin{tabular}{|c|c|c|c|}
\hline \multirow{2}{*}{$\begin{array}{l}\text { Smarter Lunchrooms } \\
\text { Awareness }\end{array}$} & \multirow{2}{*}{$\begin{array}{l}\text { A dummy variable that identifies whether the FSDs } \\
\text { have heard of Smarter Lunchroom Approach }\end{array}$} & 1 if yes & 21.77 \\
\hline & & 0 if no or don't know/unsure & 78.23 \\
\hline \multirow{7}{*}{$\begin{array}{l}\text { Smarter Lunchroom } \\
\text { Training }\end{array}$} & \multirow{7}{*}{$\begin{array}{l}\text { A categorical variable that identifies what type of } \\
\text { Smarter Lunchroom training FSDs have received } \\
\text { (conditional to a positive response to Smarter } \\
\text { Lunchroom Awareness question above) }\end{array}$} & Attended a seminar & 3.70 \\
\hline & & Viewed a Webinar & 1.85 \\
\hline & & Took online training & 0.33 \\
\hline & & Attended a lecture/talk & 2.59 \\
\hline & & Other & 1.79 \\
\hline & & None & 7.09 \\
\hline & & Missing & 82.65 \\
\hline \multirow{3}{*}{$\begin{array}{l}\text { Smarter Lunchroom } \\
\text { Change }\end{array}$} & \multirow{3}{*}{$\begin{array}{l}\text { A dummy variable that identifies whether FSDs } \\
\text { made any changes to their lunchroom practices } \\
\text { specifically as a result of Smarter Lunchroom } \\
\text { approach }\end{array}$} & 1 if yes & 4.13 \\
\hline & & 0 if no or don't know/unsure & 5.35 \\
\hline & & Missing data & 90.52 \\
\hline
\end{tabular}

* - Food service directors can have more than one organizational affiliation. Therefore, the frequencies do not sum up to $100 \%$ 
Table 2: Characteristics That Influence the Food Service Directors (FSDs) Awareness of Smarter Lunchroom (SL) Program and the Healthier Changes Made at School Cafeterias

\begin{tabular}{|c|c|c|c|}
\hline \multirow[t]{2}{*}{ Variable } & $\begin{array}{l}\text { FSDs' Awareness of the } \\
\text { SL Approach: } \\
\text { a Logit model } \\
(n=8135)\end{array}$ & $\begin{array}{c}\text { FSDs Made at Least One } \\
\text { SL Proposed Change: } \\
\text { a Logit model } \\
(n=1772)\end{array}$ & $\begin{array}{l}\text { Number of Healthy } \\
\text { Changes Made: } \\
\text { an OLS model } \\
(\mathrm{n}=8135)\end{array}$ \\
\hline & \multicolumn{3}{|c|}{$\begin{array}{l}\text { Coefficient } \\
\text { (St. Err.) }\end{array}$} \\
\hline Constant & $\begin{array}{l}-1.53 * * * \\
(0.19)\end{array}$ & $\begin{array}{l}-1.89 * * * \\
(0.31)\end{array}$ & $\begin{array}{l}2.90 * * * \\
(0.08)\end{array}$ \\
\hline FSD's Gender ( 1 if female, 0 if male) & $\begin{array}{l}-0.39 * * * \\
(0.17)\end{array}$ & $\begin{array}{l}0.42^{* *} \\
(0.17)\end{array}$ & $\begin{array}{c}0.09 * \\
(0.05)\end{array}$ \\
\hline $\begin{array}{l}\text { FSDs' Years of Experience ( } 1 \text { if } 6-10 \text { years of } \\
\text { experience, } 0 \text { otherwise) }\end{array}$ & $\begin{array}{l}-0.26^{* *} \\
(0.12)\end{array}$ & $\begin{array}{r}-0.16 \\
(0.18)\end{array}$ & $\begin{array}{r}-0.02 \\
(0.05)\end{array}$ \\
\hline $\begin{array}{l}\text { FSDs' Years of Experience ( } 1 \text { if } 11-15 \text { years of } \\
\text { experience, } 0 \text { otherwise) }\end{array}$ & $\begin{array}{l}-0.23 * * \\
(0.12)\end{array}$ & $\begin{array}{r}-0.18 \\
(0.18)\end{array}$ & $\begin{array}{r}-0.06 \\
(0.05)\end{array}$ \\
\hline $\begin{array}{l}\text { FSDs' Years of Experience ( } 1 \text { if } 16-20 \text { years of } \\
\text { experience, } 0 \text { otherwise) }\end{array}$ & $\begin{array}{l}-0.35 * * * \\
(0.12)\end{array}$ & $\begin{array}{r}-0.18 \\
(0.18)\end{array}$ & $\begin{array}{l}-0.01 \\
(0.05)\end{array}$ \\
\hline $\begin{array}{l}\text { FSDs' Years of Experience ( } 1 \text { if more than } 21 \\
\text { years of experience, } 0 \text { otherwise) }\end{array}$ & $\begin{array}{c}0.01 \\
(0.11)\end{array}$ & $\begin{array}{c}-0.14 \\
(0.16)\end{array}$ & $\begin{array}{l}-0.14 * * * \\
(0.05)\end{array}$ \\
\hline $\begin{array}{l}\text { FSDs' Affiliation to Any Nutritional } \\
\text { Organization ( } 1 \text { if a member of any organization, } \\
0 \text { otherwise) }\end{array}$ & $\begin{array}{l}0.70 * * * \\
(0.08)\end{array}$ & $\begin{array}{r}-0.09 \\
(0.13)\end{array}$ & $\begin{array}{l}0.14^{* * *} \\
(0.03)\end{array}$ \\
\hline Had a training ( 0 if no training, 1 if any training) & $\begin{array}{l}6.52 * * * \\
(0.36)\end{array}$ & $\begin{array}{l}1.75 * * * \\
(0.11)\end{array}$ & $\begin{array}{l}0.33 * * * \\
(0.05)\end{array}$ \\
\hline Middle school & $\begin{array}{l}0.16^{*} \\
(0.09)\end{array}$ & $\begin{array}{l}0.30 * * \\
(0.14)\end{array}$ & $\begin{array}{c}0.05 \\
(0.04)\end{array}$ \\
\hline High school & $\begin{array}{l}0.33 * * * \\
(0.08)\end{array}$ & $\begin{array}{l}0.28 * * \\
(0.13)\end{array}$ & $\begin{array}{c}0.05 \\
(0.03)\end{array}$ \\
\hline $\begin{array}{l}\text { Number of students served ( } 1 \text { if from } 100 \text { to } 499 \text {, } \\
0 \text { otherwise) }\end{array}$ & $\begin{array}{r}-0.11 \\
(0.12)\end{array}$ & $\begin{array}{c}0.26 \\
(0.19)\end{array}$ & $\begin{array}{l}0.25 * * * \\
(0.05)\end{array}$ \\
\hline
\end{tabular}




\begin{tabular}{|c|c|c|c|c|}
\hline \multicolumn{2}{|c|}{$\begin{array}{l}\text { Number of students served ( } 1 \text { if from } 500 \text { to } 999, \\
0 \text { otherwise) }\end{array}$} & $\begin{array}{l}-0.12 \\
(0.14)\end{array}$ & $\begin{array}{c}0.09 \\
(0.21)\end{array}$ & $\begin{array}{l}0.35^{* * *} \\
(0.06)\end{array}$ \\
\hline \multicolumn{2}{|c|}{$\begin{array}{l}\text { Number of students served ( } 1 \text { if more than } 1000 \text {, } \\
0 \text { otherwise) }\end{array}$} & $\begin{array}{c}-0.08 \\
(0.19)\end{array}$ & $\begin{array}{c}0.11 \\
(0.30)\end{array}$ & $\begin{array}{l}0.51^{* * *} \\
(0.08)\end{array}$ \\
\hline $\begin{array}{l}\% \text { of students qualifying } \\
\text { for Free/Reduced meals }\end{array}$ & $\begin{array}{l}25-34 \% \\
35-44 \% \\
45-54 \% \\
55-64 \% \\
65-74 \% \\
75 \% \text { or more }\end{array}$ & $\begin{array}{c}-0.34 * * \\
(0.14) \\
-0.15 \\
(0.13) \\
-0.12 \\
(0.12) \\
-0.27^{* *} \\
(0.14) \\
-0.27^{*} \\
(0.14) \\
-0.24^{* *} \\
(0.11)\end{array}$ & $\begin{array}{c}-0.29 \\
(0.19) \\
-0.11 \\
(0.19) \\
-0.02 \\
(0.19) \\
0.28 \\
(0.20) \\
0.33 \\
(0.22) \\
0.33^{*} \\
(0.18)\end{array}$ & $\begin{array}{c}-0.07 \\
(0.05) \\
-0.14^{* * *} \\
(0.05) \\
-0.11^{* *} \\
(0.05) \\
-0.17^{* * *} \\
(0.05) \\
-0.13^{* *} \\
(0.06) \\
0.04 \\
(0.05)\end{array}$ \\
\hline Urban index & & $\begin{array}{l}0.03 * * * \\
(0.01) \\
\end{array}$ & $\begin{array}{l}0.03 * * \\
(0.02) \\
\end{array}$ & $\begin{aligned} & 0.04 * * * \\
&(<0.01)\end{aligned}$ \\
\hline
\end{tabular}

* $-\mathrm{p}<0.10, \quad * *-\mathrm{p}<0.05, \quad * * *-\mathrm{p}<0.01$ 
Table 3: Smarter Lunchrooms (SL) Awareness/Adoption and Food Service Directors' Organizational Affiliation Differ Across Training Sessions

\begin{tabular}{|c|c|c|c|c|c|c|c|}
\hline & \multicolumn{5}{|c|}{ Type of training } & \multicolumn{2}{|c|}{ ANOVA } \\
\hline & Seminar & Webinar & $\begin{array}{c}\text { Online } \\
\text { training }\end{array}$ & Lecture & Other & \multirow{2}{*}{ F-test } & \multirow{2}{*}{$\begin{array}{c}\text { p- } \\
\text { value }\end{array}$} \\
\hline & $\begin{array}{l}\text { Mean } \\
\text { (S.D.) }\end{array}$ & $\begin{array}{l}\text { Mean } \\
\text { (S.D.) }\end{array}$ & $\begin{array}{l}\text { Mean } \\
\text { (S.D.) }\end{array}$ & $\begin{array}{l}\text { Mean } \\
\text { (S.D.) }\end{array}$ & $\begin{array}{l}\text { Mean } \\
\text { (S.D.) }\end{array}$ & & \\
\hline SL Awareness & $\begin{array}{c}0.997 \\
(0.058)\end{array}$ & $\begin{array}{c}0.987 \\
(0.115)\end{array}$ & $\begin{array}{c}0.963 \\
(0.192)\end{array}$ & $\begin{array}{c}0.981 \\
(0.137)\end{array}$ & $\begin{array}{c}1.000 \\
(0.000)\end{array}$ & 1.63 & 0.149 \\
\hline $\begin{array}{l}\text { Made any SL } \\
\text { Proposed Change }\end{array}$ & $\begin{array}{c}0.697 \\
(0.46)\end{array}$ & $\begin{array}{c}0.584 \\
(0.495)\end{array}$ & $\begin{array}{c}0.615 \\
(0.496)\end{array}$ & $\begin{array}{c}0.668 \\
(0.472)\end{array}$ & $\begin{array}{c}0.568 \\
(0.497)\end{array}$ & $148.79 * * *$ & 0.000 \\
\hline $\begin{array}{l}\text { Total number of } \\
\text { SL proposed } \\
\text { changes }\end{array}$ & $\begin{array}{c}3.834 \\
(1.361)\end{array}$ & $\begin{array}{c}3.921 \\
(1.304)\end{array}$ & $\begin{array}{c}4.148 \\
(1.231)\end{array}$ & $\begin{array}{c}3.763 \\
(1.250)\end{array}$ & $\begin{array}{r}3.699 \\
(1.371)\end{array}$ & $12.16^{* * *}$ & 0.000 \\
\hline $\begin{array}{l}\text { Member of State's } \\
\text { School Nutritional } \\
\text { Association }\end{array}$ & $\begin{array}{c}0.754 \\
(0.431)\end{array}$ & $\begin{array}{c}0.762 \\
(0.428)\end{array}$ & $\begin{array}{c}0.593 \\
(0.501)\end{array}$ & $\begin{array}{c}0.673 \\
(0.470)\end{array}$ & $\begin{array}{c}0.568 \\
(0.497)\end{array}$ & $5.15 * * *$ & 0.000 \\
\hline $\begin{array}{l}\text { Member of the } \\
\text { National School } \\
\text { Nutritional } \\
\text { Association }\end{array}$ & $\begin{array}{c}0.056 \\
(0.231)\end{array}$ & $\begin{array}{c}0.053 \\
(0.225)\end{array}$ & $\begin{array}{c}0.111 \\
(0.320)\end{array}$ & $\begin{array}{c}0.038 \\
(0.191)\end{array}$ & $\begin{array}{c}0.089 \\
(0.286)\end{array}$ & 1.11 & 0.355 \\
\hline $\begin{array}{l}\text { Member of } \\
\text { Academy of } \\
\text { Nutrition and } \\
\text { Dietetics }\end{array}$ & $\begin{array}{c}0.023 \\
(0.151)\end{array}$ & $\begin{array}{c}0.007 \\
(0.081)\end{array}$ & $\begin{array}{c}0.000 \\
(0.000)\end{array}$ & $\begin{array}{c}0.005 \\
(0.069)\end{array}$ & $\begin{array}{c}0.007 \\
(0.083)\end{array}$ & 1.69 & 0.133 \\
\hline $\begin{array}{l}\text { Member of other } \\
\text { nutritional } \\
\text { organization }\end{array}$ & $\begin{array}{c}0.020 \\
(0.140)\end{array}$ & $\begin{array}{c}0.020 \\
(0.140)\end{array}$ & $\begin{array}{c}0.037 \\
(0.192)\end{array}$ & $\begin{array}{c}0.014 \\
(0.119)\end{array}$ & $\begin{array}{c}0.103 \\
(0.305)\end{array}$ & $9.69 * * *$ & 0.000 \\
\hline $\begin{array}{l}\text { Not a member of } \\
\text { any nutritional } \\
\text { organization }\end{array}$ & $\begin{array}{c}0.146 \\
(0.354)\end{array}$ & $\begin{array}{c}0.159 \\
(0.367)\end{array}$ & $\begin{array}{c}0.259 \\
(0.447)\end{array}$ & $\begin{array}{c}0.270 \\
(0.445)\end{array}$ & $\begin{array}{c}0.233 \\
(0.424)\end{array}$ & $5.48 * * *$ & 0.000 \\
\hline
\end{tabular}


Table 4: Smarter Lunchrooms Adoption and Number of Changes Made Differ Based on Food Service Directors' Professional Membership

\begin{tabular}{|c|c|c|c|c|c|c|}
\hline & \multicolumn{6}{|c|}{ Professional Membership } \\
\hline & $\begin{array}{c}\text { State's } \\
\text { School } \\
\text { Nutrition } \\
\text { Association } \\
(\mathrm{n}=\mathbf{4 1 3 8})\end{array}$ & $\begin{array}{c}\text { The } \\
\text { National } \\
\text { School } \\
\text { Nutrition } \\
\text { Association } \\
(\mathbf{n}=1166)\end{array}$ & $\begin{array}{c}\text { Academy } \\
\text { of } \\
\text { Nutrition } \\
\text { and } \\
\text { Dietetics } \\
(n=134)\end{array}$ & $\begin{array}{c}\text { Society } \\
\text { for } \\
\text { Nutrition } \\
\text { Education } \\
\text { and } \\
\text { Behavior } \\
(n=68)\end{array}$ & $\begin{array}{c}\text { Other } \\
(n=221)\end{array}$ & $\begin{array}{c}\text { None } \\
(n=2,545)\end{array}$ \\
\hline & $\begin{array}{l}\text { Mean } \\
\text { (S.D.) }\end{array}$ & $\begin{array}{l}\text { Mean } \\
\text { (S.D.) }\end{array}$ & $\begin{array}{l}\text { Mean } \\
\text { (S.D.) }\end{array}$ & $\begin{array}{l}\text { Mean } \\
\text { (S.D.) }\end{array}$ & $\begin{array}{l}\text { Mean } \\
\text { (S.D.) }\end{array}$ & $\begin{array}{l}\text { Mean } \\
\text { (S.D.) }\end{array}$ \\
\hline $\begin{array}{l}\text { Aware of Smarter } \\
\text { Lunchroom Approach }\end{array}$ & $\begin{array}{c}0.288 \\
(0.453)\end{array}$ & $\begin{array}{c}0.247 \\
(0.431)\end{array}$ & $\begin{array}{c}0.336 \\
(0.474)\end{array}$ & $\begin{array}{c}0.206 \\
(0.407)\end{array}$ & $\begin{array}{c}0.196 \\
(0.397)\end{array}$ & $\begin{array}{c}0.134 \\
(0.341)\end{array}$ \\
\hline $\begin{array}{l}\text { Had a Smarter } \\
\text { Lunchroom Training }\end{array}$ & $\begin{array}{c}0.141 \\
(0.348)\end{array}$ & $\begin{array}{c}0.042 \\
(0.201)\end{array}$ & $\begin{array}{c}0.075 \\
(0.264)\end{array}$ & $\begin{array}{c}0.000 \\
(0.000)\end{array}$ & $\begin{array}{c}0.067 \\
(0.250)\end{array}$ & $\begin{array}{c}0.054 \\
(0.225)\end{array}$ \\
\hline $\begin{array}{l}\text { Total number of changes } \\
\text { made }\end{array}$ & $\begin{array}{c}3.553 \\
(1.279)\end{array}$ & $\begin{array}{c}3.819 \\
(1.316)\end{array}$ & $\begin{array}{l}3.970 \\
(1.387)\end{array}$ & $\begin{array}{c}4.632 \\
(1.208)\end{array}$ & $\begin{array}{c}3.680 \\
(1.401)\end{array}$ & $\begin{array}{c}3.401 \\
(1.299)\end{array}$ \\
\hline
\end{tabular}

